\title{
Removal of grazers alters the response of tundra soil carbon to warming and enhanced nitrogen availability
}

\author{
Henni Ylänne (D) $, 1,2,6,9$ Elina Kaarlejärvi,${ }^{3,4,7}$ Maria Väisänen, ${ }^{1,8}$ Minna K. Männistö, ${ }^{5}$ Saija H. K. Ahonen, ${ }^{2}$ \\ Johan OlOFSSON, ${ }^{3}$ and SARI STARK ${ }^{1}$ \\ ${ }^{1}$ Arctic Center, University of Lapland, P.O. Box 122, Rovaniemi FI-96101 Finland \\ ${ }^{2}$ Department of Ecology and Genetics, University of Oulu, P.O. Box 3000, Oulu FI-90100 Finland \\ ${ }^{3}$ Department of Ecology and Environmental Sciences, Umeå University, Umeå SE-90187 Sweden \\ ${ }^{4}$ Department of Biology, Vrije Universiteit Brussel (VUB), Pleinlaan 2, Brussel B-1050 Belgium \\ ${ }^{5}$ Natural Resources Institute Finland (Luke), Eteläranta 55, Rovaniemi FI-96300 Finland
}

Citation: Ylänne H., E. Kaarlejärvi, M. Väisänen, M. K. Männistö, S. H. K. Ahonen, J. Olofsson, and S. Stark. 2020. Removal of grazers alters the response of tundra soil carbon to warming and enhanced nitrogen availability. Ecological Monographs 90(1):e01396. 10.1002/ecm.1396

Abstract. The circumpolar Arctic is currently facing multiple global changes that have the potential to alter the capacity of tundra soils to store carbon. Yet, predicting changes in soil carbon is hindered by the fact that multiple factors simultaneously control processes sustaining carbon storage and we do not understand how they act in concert. Here, we investigated the effects of warmer temperatures, enhanced soil nitrogen availability, and the combination of these on tundra carbon stocks at three different grazing regimes: on areas with over 50 -yr history of either light or heavy reindeer grazing and in 5-yr-old exlosures in the heavily grazed area. In line with earlier reports, warming generally decreased soil carbon stocks. However, our results suggest that the mechanisms by which warming decreases carbon storage depend on grazing intensity: under long-term light grazing soil carbon losses were linked to higher shrub abundance and higher enzymatic activities, whereas under long-term heavy grazing, carbon losses were linked to drier soils and higher enzymatic activities. Importantly, under enhanced soil nitrogen availability, warming did not induce soil carbon losses under either of the long-term grazing regimes, whereas inside exclosures in the heavily grazed area, also the combination of warming and enhanced nutrient availability induced soil carbon loss. Grazing on its own did not influence the soil carbon stocks. These results reveal that accounting for the effect of warming or grazing alone is not sufficient to reliably predict future soil carbon storage in the tundra. Instead, the joint effects of multiple global changes need to be accounted for, with a special focus given to abrupt changes in grazing currently taking place in several parts of the Arctic.

Key words: fertilization; herbivory; land use; open-top chamber; Rangifer tarandus; reindeer; SEM; soil carbon storage.

\section{INTRODUCTION}

A multitude of global changes are currently occurring across the Arctic and are anticipated to become more common in the years to come. Not only is the ongoing anthropogenic warming inducing a rise in temperatures at twice the rate of the global average (Hoegh-Guldberg et al. 2018), but also soil nitrogen availability is

Manuscript received 22 January 2019; revised 30 August 2019; accepted 10 October 2019. Corresponding Editor: Aimée T. Classen.

${ }^{6}$ Present address: Centre for Environmental and Climate Research, Lund University, P. O. Box 118, Lund SE-221 00 Sweden.

${ }^{7}$ Present address: Research Centre for Ecological Change, Organismal and Evolutionary Biology, University of Helsinki, P.O. Box 65 (Viikinkaari 1), Helsinki FI-00014 Finland.

${ }^{8}$ Present address: Department of Ecology and Genetics, University of Oulu, P.O. Box 3000, Oulu FI-90100 Finland.

${ }^{9}$ E-mail: henni.ylanne@cec.lu.se predicted to increase due to microbially mediated mineralization that is stimulated by warmer temperatures, drier soils (Jiang et al. 2016) and the expansion of deciduous shrubs (Myers-Smith et al. 2011). Most drastically, soil nitrogen availability could change in response to stochastic atmospheric deposition events resulting from polluted air masses arising from industry (e.g., Kühnel et al. 2013). Such extreme nitrogen deposition events are predicted to become more common due to increased cyclonic activity and precipitation over the Arctic (Choudhary et al. 2016) with the potential to pose detrimental effects on Arctic ecosystems that inherently have low nitrogen availability and low rates of atmospheric nitrogen deposition ( 0.1 to $\sim \mathrm{g} \mathrm{N} \cdot \mathrm{m}^{-2} \cdot \mathrm{yr}^{-1}$; Choudhary et al. 2016). Simultaneously with these abiotic changes, traditional means of land use in the Arctic, such as reindeer (Rangifer tarandus L.) husbandry, experience large-scale transformations owing to both societal and environmental changes (Forbes et al. 2016, Uboni et al. 
2016). These affect the vast majority of habitats in northern Eurasia where reindeer husbandry has constituted a major means of land use and livelihood for centuries. Yet how reindeer shape ecosystem responses to other global changes remains, for the most part, unexplored. Simultaneous investigation of grazing and other drivers on ecosystem processes is crucial, since their cumulative effects may not be additive, but instead synergistic or antagonistic (Tylianakis et al. 2008).

Understanding the joint effects of abiotic and biotic global changes on soil carbon storage is of particular importance in the Arctic, where one-half of the global soil carbon is stored (Tarnocai et al. 2009). According to some estimates, the current warming has already stimulated the microbial-mediated breakdown of soil organic matter more than plant carbon input to soils contributing to an amplified carbon cycle (Belshe et al. 2016). As soil carbon turnover is more sensitive to temperature increases in cold climates than in warm climates (Koven et al. 2017), a further increase in temperatures is projected to lead to soil carbon losses particularly from the Arctic areas. In addition to warming, also changes in soil nutrient availability could alter processes governed by soil microbes and, through destabilization of accumulated soil carbon, lead to reduced soil carbon storage (Hartley et al. 2010, Street et al. 2018).

As grazing patterns affect vegetation, soil microclimate, and nutrient availability, grazers may have a direct effect on ecosystem carbon storage (Zimov et al. 2009). Yet, they can also mediate how the ecosystem responds to other environmental changes (Tylianakis et al. 2008, Callaghan et al. 2013). The role of herbivores could be pronounced in locations where grazers suppress the abundance and growth of deciduous shrubs (Olofsson et al. 2004, 2009, Bråthen et al. 2017) that otherwise may respond positively to warmer temperatures and enhanced nutrient availability and induce soil carbon losses (Mack et al. 2004, Parker et al. 2015). This warming and fertilization-induced shift in shrub abundance, and thereby in the shrub-mediated carbon sequestration processes, is unlikely to take place in high herbivore densities.

In subarctic tundra, grazers may decrease ecosystems' carbon sink capacity rapidly through suppressed productivity (Cahoon et al. 2012, Metcalfe and Olofsson 2015) or in the longer term by inducing a vegetation transition to a state that maintains higher ecosystem respiration (Väisänen et al. 2014). This influence of grazing may determine how the ecosystem responds to global changes and how ecosystems' carbon storage develops with time. Yet previous studies investigating interactions between grazing and warming have shown contrasting effects on carbon fluxes: in Greenland, experimental warming increased growing seasonal productivity and carbon sink only in the absence of grazers (e.g., a negative effect of grazing; Cahoon et al. 2012), whereas in northern Scandinavia, the warming-induced increase in respiration was counterbalanced by increased productivity only under grazing (e.g., a positive effect of grazing;
Väisänen et al. 2014). These contrasting results of grazer-warming interactions on carbon fluxes might depend on the intensity of grazing (Sjögersten et al. 2012) or the time passed since the change in grazing intensity (Haynes et al. 2014). Further, the effects of grazer exclosures are likely different from the comparison among long-term grazing regimes as the grazing-induced changes in ecosystem processes may have become independent of the actual grazing event (Stark and Väisänen 2014, Egelkraut et al. 2018). If heavy grazing suddenly stops, this may, in contrast to the long-term grazing difference, increase plant biomass (Ravolainen et al. 2011), productivity (Cahoon et al. 2012), litter accumulation, and soil microbial activity (Francini et al. 2014).

In this study, we assess how $5 \mathrm{yr}$ of experimental warming and increased soil nitrogen availability interact with both long- and short-term differences in grazing intensity in shaping ecosystem carbon stocks and the processes underlying the changes. We use an over 50yr-old reindeer fence that separates a lightly grazed shrub-dominated tundra from a heavily grazed graminoid-dominated tundra, where the different grazing histories on the two sides of the fence have created different ecosystem states (Olofsson et al. 2004). In addition to the long-term grazing difference, we also established short-term grazer exclosures on the heavily grazed side of the fence to account for the effect of a sudden grazing cessation. Previously, it has been shown that, in the second and third year of the experiment, warming decreased the carbon sink under light grazing but this effect was negated by fertilization (Väisänen et al. 2014). Notably, the treatments did not influence the carbon sink under heavy grazing and inside the short-term grazer exclosures (Väisänen et al. 2014). As the components of carbon sink, primary productivity and respiration, constitute the main pathways for carbon stock changes on dry tundra heaths, we expected the same patterns to be reflected in ecosystem carbon stocks. We thus predicted that warming decreases ecosystem carbon only under light grazing without fertilization. Besides assessing the responses of ecosystem carbon stocks to warming and fertilization, we also analyzed the pathways leading to changes in soil carbon storage under different grazing intensities and report the accompanied changes both above- and belowground.

\section{Materials And Methods}

\section{Study area}

The study was conducted $100 \mathrm{~m}$ above the treeline on a northern slope of Raisduoddar, northern Norway $\left(69^{\circ} 31^{\prime} 29 \mathrm{~N}, 21^{\circ} 19^{\prime} 16 \mathrm{E}\right.$; altitude $430-570 \mathrm{~m}$ above sea level). This in a non-permafrost area with glacial tills as the dominant mineral soil type. As typical for tundra soils, only weak podzolic profiles are developed. At the site, a continuous soil organic layer of approximately $4.25 \mathrm{~cm}$ is found above the mineral soil layer (Ylänne 
et al. 2018). The area is bisected by a pasture rotation fence, been in place at least since 1966, which creates a legal border between the reindeer summer ranges and their migration range. The fence is built along a slope, and similar bedrock, topography, exposure, and hydrology are found at both sides of the fence (e.g., te Beest et al. 2016). The summer range side of the fence experiences heavy grazing (HG) intensity for a few weeks during annual reindeer migrations in August, whereas the migration range is subjected to grazing for only a short period of time (referred to as light grazing intensity, LG). More than $50 \mathrm{yr}$ of grazing difference has considerably altered vegetation composition. Dwarf birch (Betula nana), mountain crowberry (Empetrum hermaphroditum), bryophytes, and lichens dominate the vegetation under light grazing, whereas graminoids and forbs form the majority of vegetation cover under heavy grazing (Olofsson et al. 2001, 2004). Along the difference in vegetation, heavy grazing has increased decomposition rates and nutrient availability and decreased the fungal : bacterial ratio in the soil when compared to the lightly grazed, shrub-dominated tundra (Olofsson et al. 2004, Stark and Väisänen 2014, Männistö et al. 2016). Heavy grazing has also decreased mycorrhizal colonization in the dominant shrub species $B$. nana and $E$. hermaphroditum, leading to a consequence that all plant species under heavy grazing seem to rely more on the inorganic nitrogen pool in their nitrogen uptake (Barthelemy et al. 2017). Further, soil temperatures are higher under graminoid dominance (Olofsson et al. 2004), and e.g., during the $5 \mathrm{yr}$ of our study, summer soil temperatures were approximately $1.7^{\circ} \mathrm{C}$ higher under HG than LG during summer months (June and July; Appendix S1: Table S1, Fig. S1).

\section{Experimental set-up}

In 2010, we set up eight blocks bisecting the fence. The blocks were $5 \times 10 \mathrm{~m}$, spaced $20 \mathrm{~m}$ apart, and represented variable topographical conditions of the slope, from exposed ridges to moist snow beds. To each block, we set four plots $\left(0.935-1 \mathrm{~m}^{2}\right)$ on both sides of the fence (HG and LG) with the randomly assigned treatments of control (Ctrl), warming (W), fertilization (F), and combined warming and fertilization (WF; Väisänen et al. 2014). Additionally, plots under HG were divided into grazed (HG) and ungrazed (HGexc) subplots with short-term exclosures (height $0.9 \mathrm{~m}$, mesh $40 \times 40 \mathrm{~mm}$ ) that were built each year (2010-2014) before reindeer migration and removed after the grazing event to avoid winter-time snow accumulation. The experimental design did not include short-term exclosures under LG due to very low grazing pressure.

Warming was implemented with open-top chambers (OTCs, diameter $120 \mathrm{~cm}$, height $40 \mathrm{~cm}$ ) set to the plots after snow melt (early June) and kept in place until the arrival of reindeer (early August) to avoid OTCs affecting the feeding behavior of reindeer. In this way, the warming treatment's direct effect was limited to approximately two months, encompassing the early and peak growing season. OTCs generally increase air and soil temperatures by $1.2^{\circ} \mathrm{C}$ and $0.8^{\circ} \mathrm{C}$, respectively, but they also induce changes in wind exposure, soil moisture, and humidity (Bokhorst et al. 2011). In this study, we did not observe an effect of OTCs on soil temperatures at $3 \mathrm{~cm}$ depth on LG and HG $(n=3$, Appendix S1: Table S1). Yet, OTCs increased ground surface temperature by $1.0^{\circ} \mathrm{C}$ and $1.8^{\circ} \mathrm{C}$ at $\mathrm{LG}$ and $\mathrm{HG}$, respectively ( $n=2$; Väisänen et al. 2014).

Fertilization was applied yearly, early in the growing season, by dissolving ammonium nitrate $\left(\mathrm{NH}_{4} \mathrm{NO}_{3}\right)$ equivalent to $10 \mathrm{~g} \mathrm{~N} / \mathrm{m}^{2}$ in $1 \mathrm{~L}$ of water and applying it to the plots. Due to logistical reasons and the high mean annual precipitation in the study area, the unfertilized plots were not watered. The nitrogen $(\mathrm{N})$ addition corresponds to the predicted soil $\mathrm{N}$ increase after a $7^{\circ} \mathrm{C}$ increase in air temperature (Mack et al. 2004). After $4 \mathrm{yr}$ of treatment, fertilization had increased soil $\mathrm{NH}_{4}^{+}-\mathrm{N}$ content per area nine-fold in LG and three-fold in $\mathrm{HG}$, regardless of the exclosures ( $\mathrm{F}$ compared to Ctrl treatment; Appendix S1: Fig. S2). The concentration of $\mathrm{NO}_{3}^{-}-\mathrm{N}$ increased similarly in all grazing intensities, and was 99-fold higher in the fertilized compared to control plots (Appendix S1: Fig. S2).

\section{Grazing and treatment effects on vegetation abundance}

After $3 \mathrm{yr}$ of treatments, the short-term exclosures had increased graminoid abundance and led to higher overall abundance of vegetation, warming had increased the abundance of shrubs and herbs, and fertilization had increased the abundance of graminoids and litter (Väisänen et al. 2014). Here, we report the development of vegetation abundance throughout the course of the experiment (2010-2014), analyzed with a modified point intercept method, where 10 vertical pins are positioned $10 \mathrm{~cm}$ away from each other on $50 \mathrm{~cm}$ wide rows (eight rows on LG, four rows on HGexc and HG in 2010-2013, and two rows in LG, HGexc and HG in 2014) and where all hits per species are counted. The recordings were done in the first half of August every year. We normalized the number of hits to hits per 100 pins and report species abundances pooled into growth forms (evergreen shrubs, deciduous shrubs, graminoids, forbs, bryophytes, and lichens).

\section{Ecosystem carbon stocks}

Ecosystem carbon stocks were sampled after $5 \mathrm{yr}$ of the experiment, in 2014, before the annual grazing period at the study site. Therefore, these do not account for the immediate grazer-induced biomass removal. Vascular aboveground biomass was collected from an area of $250 \mathrm{~cm}^{2}$ and sorted into growth forms. Bryophyte, lichen, and litter biomass was hand-picked from cored ground-layer samples (diameter $119 \mathrm{~mm}$ ). Litter included both cryptogam and vascular litter. Soil and 
root biomass was collected with three or four soil cores (diameter $29 \mathrm{~mm}$ ) underneath the litter layer until the corer hit large stones and separated later into organic and mineral soil layers. This procedure will not give a comprehensive estimate of mineral soil $\mathrm{C}$ stocks. However, large stones are likely to be found at similar depth regardless of the treatments and the grazing, and therefore, this procedure can be assumed to give a reliable estimate of treatment-induced changes in mineral soil C. The soil layers were later homogenized separately ( $2 \mathrm{~mm}$ sieve), and the root biomass was obtained from the sieving residue after washing. All vegetative, litter, and soil biomass was dried $\left(60^{\circ} \mathrm{C}, 70 \mathrm{~h}\right)$, weighed, milled (RETSCH MM 2000, Retsch Gmbh, Haan, Germany) and analyzed for carbon and nitrogen contents $(\mathrm{C}-\mathrm{H}-\mathrm{N}$ Element Analyser EA1110; CE Instruments Ltd., Wigan, UK, SFS-EN 15104:2011). From the sieved soil samples, we determined soil moisture (drying at $100^{\circ} \mathrm{C}$, $12 \mathrm{~h}$ ), organic matter content (loss on ignition at $475^{\circ} \mathrm{C}$, $4 \mathrm{~h}$ ) and bulk density (dry mass/volume).

\section{Soil inorganic $N$ pools and potential enzymatic activity}

To determine soil inorganic $\mathrm{N}$ pools and microbial activity, we collected composite soil samples (three to seven soil cores, diameter $25 \mathrm{~mm}$ ) from the organic layer three times during the growing season in 2013 (19 June, 16 July, and 6 August). We recorded depth of the organic layer, sieved the samples (mesh $2 \mathrm{~mm}$ ) and stored these at $+4^{\circ} \mathrm{C}$ for further analyses. Within $48-72 \mathrm{~h}$ after sampling, soils were extracted with $0.5 \mathrm{~mol} / \mathrm{L} \mathrm{K}_{2} \mathrm{SO}_{4}$ for $2 \mathrm{~h}$, and the inorganic soil ammonium $\left(\mathrm{NH}_{4}^{+}-\mathrm{N}\right)$ and nitrate $\left(\mathrm{NO}_{3}^{-}-\mathrm{N}\right)$ concentrations were analyzed with colorimetrical analyses (SFS 3032, UV-1700 spectrometer, Shimadzu, Kyoto, Japan for $\mathrm{NH}_{4}^{+}-\mathrm{N}$; SFS-EN ISO 133395CFA, AA3 analyser, Seal Analytical, Mequon, WI, USA for $\mathrm{NO}_{3}^{-}-\mathrm{N}$ ). To depict changes in microbial enzyme production, we analyzed the potential activities of five hydrolytic and one oxidative extracellular enzymes involved in the decomposition of soil organic matter: the hydrolytic $\beta$-glucosidase (BG), $\beta$-N-acetylglucosaminidase (NAG), leucine aminopeptidase (LAP), acid phosphatase (AP), amidohydrolase (commonly known as urease; $\mathrm{U}$ ), and the oxidative phenol oxidase (POX). The potential activities were determined within $5 \mathrm{~d}$ after sampling using previously established methods (Boerner et al. 2000, Sinsabaugh et al. 2000, Allison et al. 2008) with the following chromogenic substrates: $5 \mathrm{mmol} / \mathrm{L}$ paranitrophenyl(pNP)- $\beta$-glucopyranoside for $\mathrm{BG}, 2 \mathrm{mmol} / \mathrm{L}$ pNP- $\beta$-N-acetylglucosaminide for NAG, $5 \mathrm{mmol} / \mathrm{L}$ leucine p-nitroanilide for LAP, $5 \mathrm{mmol} / \mathrm{L}$ pNP-phosphate for AP, $30 \mathrm{mmol} / \mathrm{L}$ urea for $\mathrm{U}$, and $50 \mathrm{mmol} / \mathrm{L}$ pyrogallol for POX. We conducted assays in sodium acetate buffer $(50 \mathrm{mmol} / \mathrm{L}, \mathrm{pH} 5.0$ that corresponds to the study site's mean soil $\mathrm{pH}, 5.13$ ). The soilsubstrate aliquots were incubated at room temperature, $5 \mu \mathrm{L}$ of $1.0 \mathrm{~mol} / \mathrm{L} \mathrm{NaOH}$ was added to $\mathrm{AP}, \mathrm{BG}$, and NAG before the supernatants were measured spectrophotometrically for their potential activities (405 nm for BG, NAG, LAP, and AP, 450 for POX, Multiskan FC microplate photometer, Thermo Scientific, Vantaa, Finland). U activity was verified by measuring the formation of $\mathrm{NH}_{4}^{+}$after $5 \mathrm{~h}$. The $100-\mu \mathrm{L}$ aliquots of supernatant were incubated with $10 \mu \mathrm{L}$ of sodium citrate, phenol nitroprusside, and hypochlorite $\left(19^{\circ} \mathrm{C}, 1 \mathrm{~h}\right)$, and absorbance was measured at $620 \mathrm{~nm}$ (Multiskan FC microplate photometer, Thermo Scientific). The absorbances of homogenate and substrate controls were subtracted from the assay absorbance. Extinction coefficients for calculating potential activities were obtained based on standard curves for paranitrophenol (BG, NAG, AP), paranitroaniline (LAP) and $\mathrm{NH}_{4} \mathrm{Cl}(\mathrm{U})$, and oxidation of pyrogallol by mushroom tyrosinase (POX). All potential activities were counted as $\mu \mathrm{mol} \cdot \mathrm{h}^{-1} \cdot \mathrm{g} \cdot \mathrm{SOM}^{-1}$ and we additionally calculated the sum of all analyzed extracellular enzyme activities (EEAs).

\section{Fungal and bacterial copy numbers}

Total genomic DNA for bacterial and fungal quantitative PCR (qPCR) was determined from plots under LG and HG in July 2013 from the same composite samples from which $\mathrm{N}$ concentrations and EEAs were analyzed. The composite soil samples were sieved in the field and subsamples of $0.1-0.5 \mathrm{~g}$ were immediately frozen in liquid nitrogen for later analysis. The DNA was extracted using a modified phenol-chloroform-isoamylalcohol (PCI) protocol (Griffiths and Whiteley 2000, Männistö et al. 2016) with $600 \mu \mathrm{L}$ of CTAB buffer in a mixture of beads $(0.7 \mathrm{~g}$ ceramic beads $[1.0 \mathrm{~mm}], 0.3 \mathrm{~g}$ glass beads $[0.1 \mathrm{~mm}]$, and two large glass beads [3.5 mm]; BioSpec, Bartlesville, $\mathrm{OH}$, USA). The fungal ITS2 and bacterial 16S rRNA gene copies in the soil samples were quantified using a Bio-Rad CFX96 Real-time thermal cycler (Bio-Rad, Hercules, California, USA). All qPCRs were run in technical triplicates of $20 \mu \mathrm{L}$ containing $10 \mu \mathrm{L}$ SSoFast EvaGreen qPCR Supermix (Bio-Rad) for bacterial and SsoAdvanced Universal SYBR Green Supermix (Bio-Rad) for fungal reactions, $0.5 \mu \mathrm{L}$ of forward and reverse primers $(10 \mathrm{mmol} / \mathrm{L})$ (Eub341F and Eub534R [Muyzer et al. 1993] for bacteria and fITS7 [Ihrmark et al. 2012] and

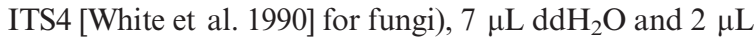
template in a 100 -fold dilution. The conditions were $98^{\circ} \mathrm{C}$ for $2 \mathrm{~min}$, followed by 40 cycles of $98^{\circ} \mathrm{C}$ for $5 \mathrm{~s}, 56^{\circ} \mathrm{C}$ for $20 \mathrm{~s}$ for bacterial qPCR and $98^{\circ} \mathrm{C}$ for $3 \mathrm{~min}$, followed by 40 cycles of $98^{\circ} \mathrm{C}$ for $15 \mathrm{~s}, 61^{\circ} \mathrm{C}$ for $60 \mathrm{~s}$ for fungal qPCR with a melt curve analysis as the final step. The standard curves were generated using genomic DNA from bacterial isolate Granulicella mallensis and fungal isolate Laccaria laccata.

\section{Statistical approach}

We used a multilevel model for mixed designs to analyze treatment effects on carbon stocks, vegetation, 
microbial communities, and activities (nlme package; Pinheiro et al. 2014), where contrasts were modified so that both LG and HGexc were compared to HG only, which enables the separate comparison of the long-term grazing intensity and the short-term exclosures within one test. In the model, the following three random factors were nested within each other: the block $(n=8)$, the block within the long-term grazing range $(n=16)$, and the pair of plots on the summer range (HG and HGexc) separated by the small fences. Grazing, warming and fertilization were treated as fixed factors in all models. Year or sampling date was included as a repeated factor to the analyses of vegetation abundance and microbial activity. All model fits were assessed with residual plots and, for the enzyme activities and vegetation change, we used square root transformations to obtain improved fit. Pairwise difference between grazing intensities and the interactions among factors were monitored with a leastsquares means post hoc test (Lenth 2016).

To test for the drivers behind soil carbon (SOC) stocks within the experimental design, we compared several linear mixed-effect models where explanatory variables were added one at a time. First, we tested how much either warming, fertilization, or one the following 20 soil and vegetation parameters explained variance in SOC: soil moisture, concentration of inorganic $\mathrm{N}$, soil $\mathrm{C}: \mathrm{N}$ ratio, the ratio of inorganic $\mathrm{N}$ to soil $\mathrm{C}$, the growing seasonal average of the individual EEAs and their sum, the multifunctionality of EEAs (Maestre et al. 2012, Jassey et al. 2018; Appendix S1: Fig. S8), the abundances of vascular vegetation, graminoids, evergreen shrubs, deciduous shrubs, all shrubs, and the cover of litter and bryophytes. The influence of each focal variable was tested both separately and depending on the grazing intensity (e.g., interaction with grazing). Log- or squareroot transformations were used for the non-normally distributed factors, and all variables were scaled (mean $=0$; $\mathrm{SD}=1$ ) before the analysis. Similar to the mixed design approach, linear mixed-effects models were built with modified contrasts for the grazing intensity and a multilevel random factor was used, where the effect of plot pair and block were nested inside the long-term grazing intensities. We compared the models based on Akaike's information criteria (package AICcmodavg; Mazerolle 2017), selected the models best fitting the data $\left(\Delta \mathrm{AIC}_{\mathrm{c}} \leq 2\right)$, and consecutively, tested whether further focal variables or their interaction with grazing increased model fit. We only permitted further explanatory variables that showed no collinearity $\left(\mathrm{GVIF}^{1 / 2 \text { d.f. }} \leq 2\right)$ with the previous variables, and run the models until the fit, assessed by $\Delta \mathrm{AIC}_{\mathrm{c}}$, no longer improved with added variables.

We used piecewise structural equation models (SEM; Lefcheck 2016) to test whether warming and fertilization impacted soil organic carbon stocks directly or through those soil and vegetation parameters that were included in the models with best fit (Appendix S1: Table S2). As all the best fitting models showed interactions with grazing, the SEM model was run for each grazing intensity separately. Prior to SEM, the vegetation parameters were combined to graminoid:shrub ratio (the abundance of forbs and graminoids divided by the abundance of deciduous and evergreen shrubs). We used the normally distributed and scaled variables and set the SEM to indicate direct and indirect effects of the warming and fertilization treatments on soil carbon stocks (Initial model in Appendix S1: Fig. S3). Blocks were set as random factors in the model. The overall fit of the path models was evaluated with Shipley's test of directed separation (Shipley 2009), which indicated an adequate model fit $(P>0.05$; Appendix S1: Table S3) for all the path models. All statistical tests were conducted with $\mathrm{R}$ software for statistical computing, version 3.1.3 (R Core Team 2012).

\section{RESUlts}

\section{Soil and ecosystem carbon storage}

Carbon in the organic soil layer comprised the largest carbon pool at our site. We found no effect of long-term or short-term grazing difference on soil carbon storage in either organic or mineral soil layer. In line with this, also total ecosystem carbon stock (i.e., the sum of soil, plant aboveground, belowground, and litter C) did not differ between the grazing treatments, even though vascular and bryophyte $\mathrm{C}$ stocks were smaller under heavy grazing compared to both long-term light grazing and the short-term exclosures (Table 1, Fig. 1).

Warming by OTCs decreased carbon in the organic soil layer under all grazing intensities $(P=0.014$, Table 1; Fig. 1). The warming-induced carbon loss in the organic soil was partly compensated by an increased carbon storage in the mineral soil layer, as we found a positive effect of warming on the mineral soil carbon stocks in all other treatments except for the unfertilized warming treatment under light grazing $(\mathrm{G} \times \mathrm{W} \times \mathrm{F}$ : $P=0.039$, Table 1 ; Fig. 1). Still, this increase in mineral soil layer was of smaller magnitude than the carbon loss from the organic soil layer. There was no effect of fertilization alone on organic or mineral soil carbon stocks. Yet, fertilization negated the warming-induced carbon loss in organic soil under long-term light and heavy grazing but not within short-term exclosures $(\mathrm{G} \times \mathrm{W} \times \mathrm{F}$ : $P=0.033$, Table 1). Regardless of the treatmentinduced changes in organic soil carbon, total ecosystem carbon stock did not differ statistically significantly among warmed and fertilized treatments at different grazing intensities (Table 1).

\section{Pathways to changes in soil carbon storage}

Structural equation modeling (SEM) revealed that warming and fertilization impact soil carbon stock mainly by altering soil and vegetation properties (Fig. 2). SEM indicated a negative link between the sum of analysed extracellular enzyme activities and the soil 


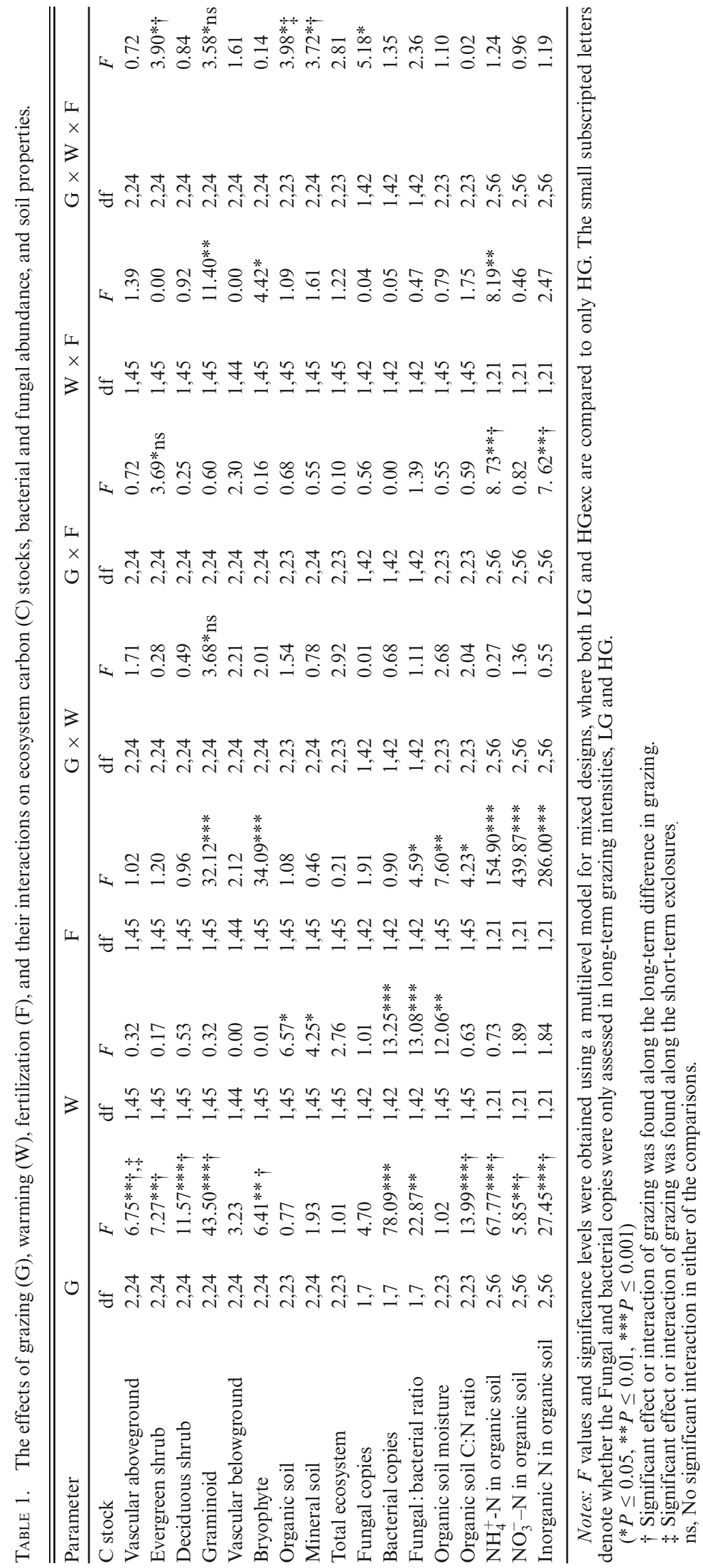




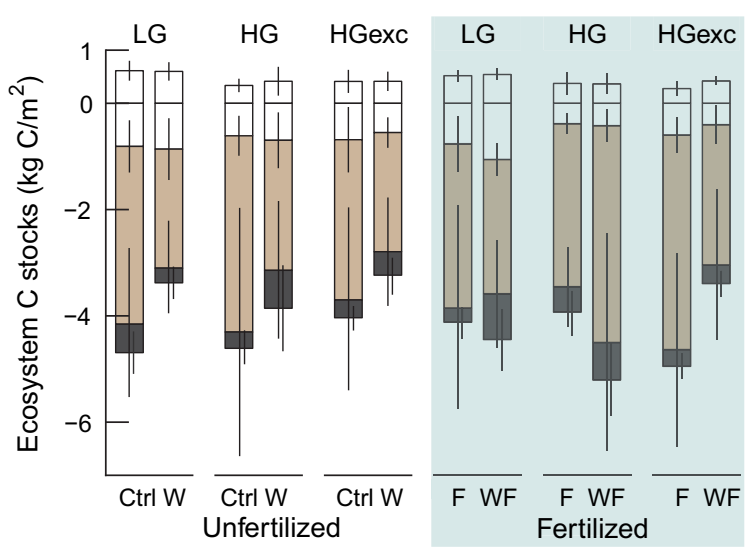

$\square$ Vegetation and litter $\square$ Organic soil $\square$ Mineral soil

FIG. 1. Effects of experimental warming and fertilization on ecosystem carbon (C) stocks after $5 \mathrm{yr}$ of treatments in control (Ctrl), warmed (W), fertilized (F), and warmed and fertilized (WF) plots under light grazing (LG), heavy grazing (HG), and within short-term exclosures (HGexc). Aboveground stocks are presented as positive values (i.e., C stocks in litter, cryptograms, and the aboveground part of the vascular vegetation; mean and 95\% confidence interval), whereas belowground stocks are shown as negative values. We tested for the effect of long-term and short-term grazing difference separately, and found a three-way grazing $\times$ warming $\times$ fertilization interaction on the organic soil C in the HG-HGexc comparison.

carbon stock under all grazing intensities (Fig. 2 and Appendix S1: Fig. S4). Under light and heavy grazing, SEM indicated that warming decreased soil moisture and the sum of analyzed extracellular enzyme activities. Additionally, under heavy grazing, soil moisture was shown to correlate negatively with the sum of analysed extracellular enzyme activities. Further, soil carbon storage was reduced by increasing shrub abundance under light grazing (Fig. 2a). In the grazing intensities where shrubs were rare (heavy grazing and short-term exclosures), soil moisture was instead a strong driver of soil carbon (Figs 2b, c). These changes were linked to the treatment effects, as a higher proportion of shrubs was found in the warmed plots under light grazing, whereas at the heavily grazed tundra, decreased soil carbon storage in warmed plots was linked to drier soils both directly but also through higher extracellular enzymatic activity (Fig. 2b). Only within the short-term exclosures, warming decreased soil carbon stocks also directly in addition to the indirect changes via soil moisture and extracellular enzyme activity.

\section{Accompanied treatment effects aboveground}

When compared to long-term heavy grazing, there was more bryophyte, deciduous, and evergreen shrub carbon under long-term light grazing, whereas graminoid carbon showed an opposite pattern (Fig. 3; Table 1). Taken together, the lightly grazed site a

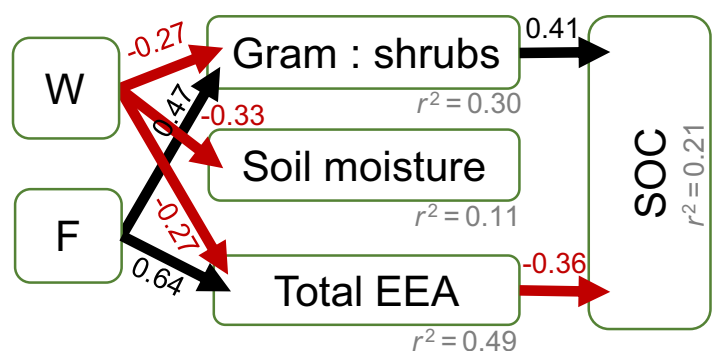

b

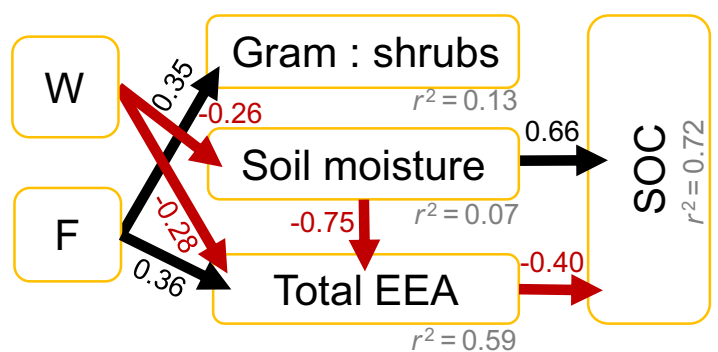

C

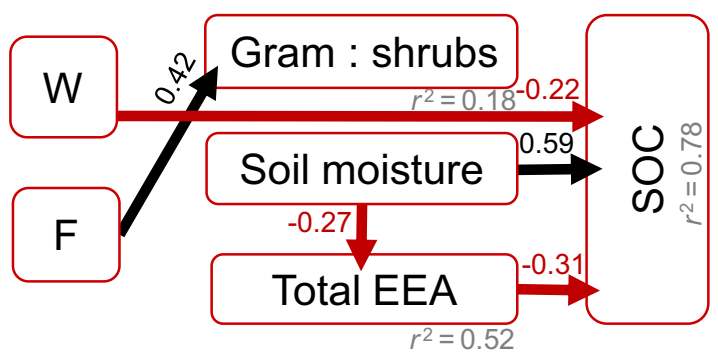

FIG. 2. The links leading to changes in soil organic carbon stocks (SOC) under (a) long-term light grazing, (b) long-term heavy grazing, and (c) within short-term exclosures under heavy grazing as identified by a piecewise structural equation model. The shown model was chosen after identifying the key drivers behind within block variation of SOC with model comparison based on Akaike's information criteria. As the best-fit model indicated interaction with grazing (Appendix S1: Table S1), the connections between the factors (W, warming; F, fertilization; gram:shrubs, graminoid:shrub ratio; organic soil moisture; and total EEA, the sum of all measured potential extracellular enzyme activities) were analyzed under each grazing intensity separately. Red arrows and red coefficients indicate negative causal relationships, whereas black arrows and coefficients mark positive relationships. The amount of variation explained, $r^{2}$, is stated for each response variable.

dominated by woody vegetation stored more carbon in both aboveground and belowground biomass than the heavily grazed site did. Short-term exclusion of grazing led to higher vascular aboveground carbon stocks in comparison to heavily grazed tundra, even though exclusion had no statistically significant effects on the biomass of individual growth forms. The abundance changes throughout the years further revealed that the exclosures increased graminoids (i.e., grasses, sedges) and litter, while decreased bryophytes and forbs $(\mathrm{G} \times \mathrm{Y}$ interactions in Appendix S1: Table. S4, Fig. S5).

In the absence of fertilization, warming increased bryophyte $\mathrm{C}$ at all grazing intensities $(\mathrm{W} \times \mathrm{F} ; P=0.04$, 
Table 1; Fig. 3) and increased evergreen $\mathrm{C}$ under $\mathrm{HG}$ and HGexc. Abundance counts further confirmed that warming affected positively deciduous shrubs, forbs, and bryophytes (vegetation development in Appendix S1: Table S4, Fig. S5). Fertilization, on the other hand, decreased bryophyte $\mathrm{C}$ at all grazing intensities $(P<0.001$, Table 1; Fig. 3). Notably, the negative effect of fertilization on bryophyte abundance was evident already in the first years of the experiment (Appendix S1: Table S4, Fig. S5). Further, fertilization increased graminoid $\mathrm{C}$, particularly when combined with warming $(\mathrm{W} \times \mathrm{F}: P=0.01$, Table 1; Fig. 3).

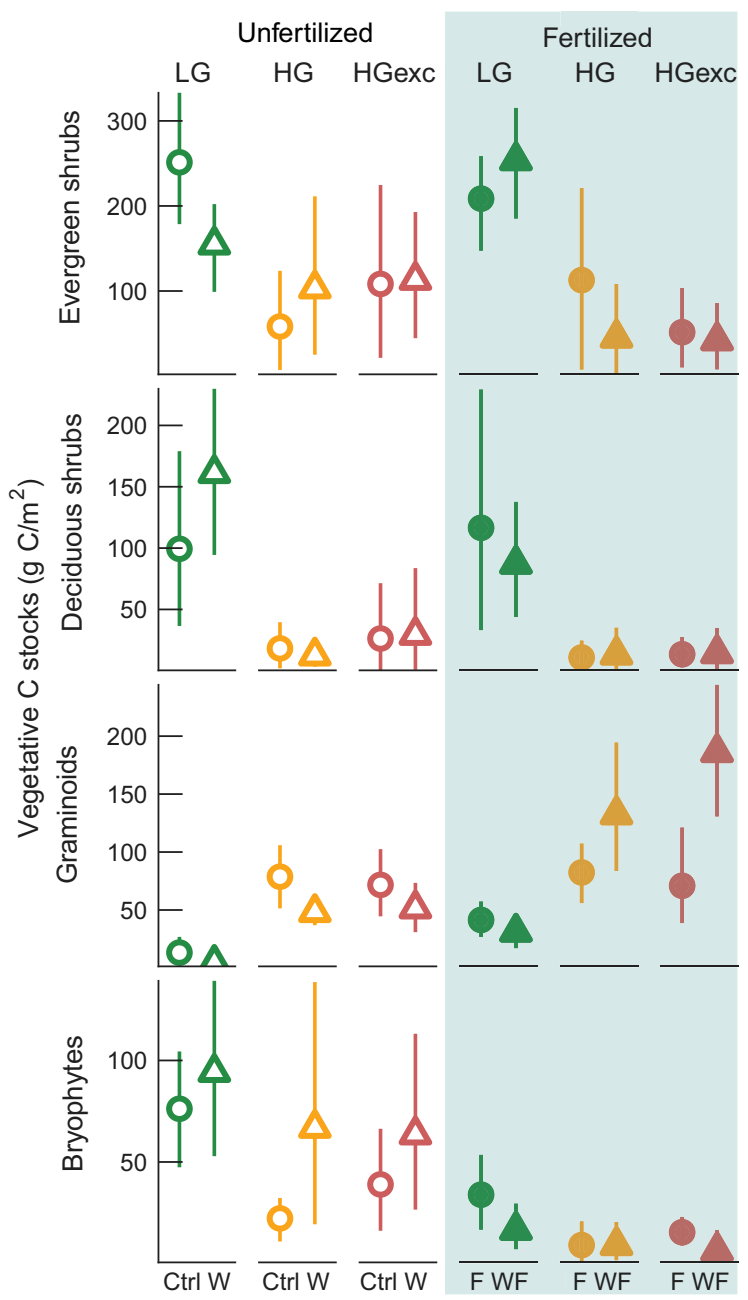

FIG. 3. Aboveground carbon stocks in the different plant growth forms in 2014. The figure summarizes the carbon (C) stocks in evergreen shrubs, deciduous shrubs, graminoids, and bryophytes (mean and 95\% confidence interval based on a bootstrap; $n=8$ ) in control (Ctrl), warmed (W), fertilized (F), and warmed and fertilized (WF) plots under light grazing (LG), heavy grazing $(\mathrm{HG})$, and inside short-term exclosures under heavy grazing (HGexc). In the statistical approach, we compare the long-term grazing difference (LG vs. HG) separately of the short-term grazing difference (HGexc vs. HG).

\section{Accompanied treatment effects belowground}

Long-term heavy grazing increased the number of bacterial copies on the study plots, leading also to a lower fungal: bacterial ratio when compared to long-term light grazing (Fig. 5). Further, the potential of microbes to produce extracellular enzymes was higher under longterm heavy grazing compared to long-term light grazing $(P=0.02$ in Appendix S1: Table S5; Fig. 4). The grazing history did not affect soil moisture, yet organic soil $\mathrm{C}: \mathrm{N}$ ratio was lower $(P<0.001)$ and the amount of inorganic $\mathrm{N}$ per area was higher $(P<0.001)$ under heavy grazing (Table 1; Appendix S1: Figs. S2 and S5). These soil properties and the total extracellular enzyme activity were similar inside and outside of the short-term exclosures (Table 1; Appendix S1: Table S5). Yet, the potential activities of individual enzymes increased with exclusion (Appendix S1: Table S5, Fig. S7). The number of bacterial and fungal copies was not assessed inside the exclosures.

We found that warming decreased soil moisture $(P=0.001$, Table 1$)$, increased the ratio of fungal: bacterial copy numbers $(P<0.001$, Table 1 ; Fig. 5) and decreased the number of bacterial copies $(P<0.001$, Table 1; Fig. 5). Warming had no effect on the total EEA, but it enhanced the potential activity activities of $\beta$-glucosidase and $\beta$ - $\mathrm{N}$-acetylglucosaminidase in June and, under light grazing, decreased the activity of acid phosphatase, the most prevalent EEA at our site (Appendix S1: Table S5, Fig. S7).

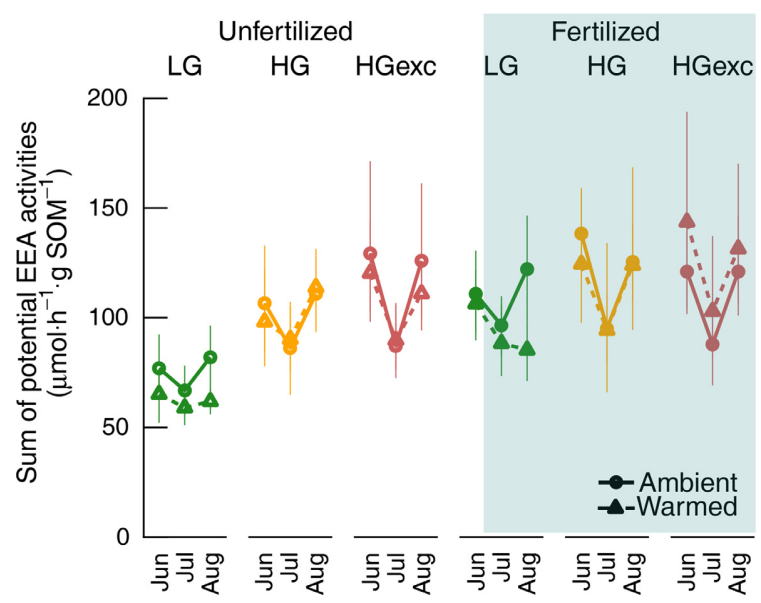

FIG. 4. The sum of six potential extracellular enzyme activities in control, warmed, fertilized, and warmed and fertilized plots under light grazing (LG), heavy grazing (HG), and exclosures under heavy grazing (HGexc; $n=8$ ). Figure represents mean and $95 \%$ confidence interval based on a bootstrap. Total EEA includes the potential activities of $\beta$-glucosidase (BG), $\mathrm{N}$-acetyl-glucosaminidase (NAG), acid phosphatase (AP), leucine aminopeptidase (LAP), phenol oxidase (POX), and urease (U) measured in year 2013. In our statistical approach, we compare the effects of $\mathrm{W}, \mathrm{F}$, and grazing separately along the longterm grazing difference (LG vs. HG) and along the short-term grazing difference (HGexc vs. HG). 


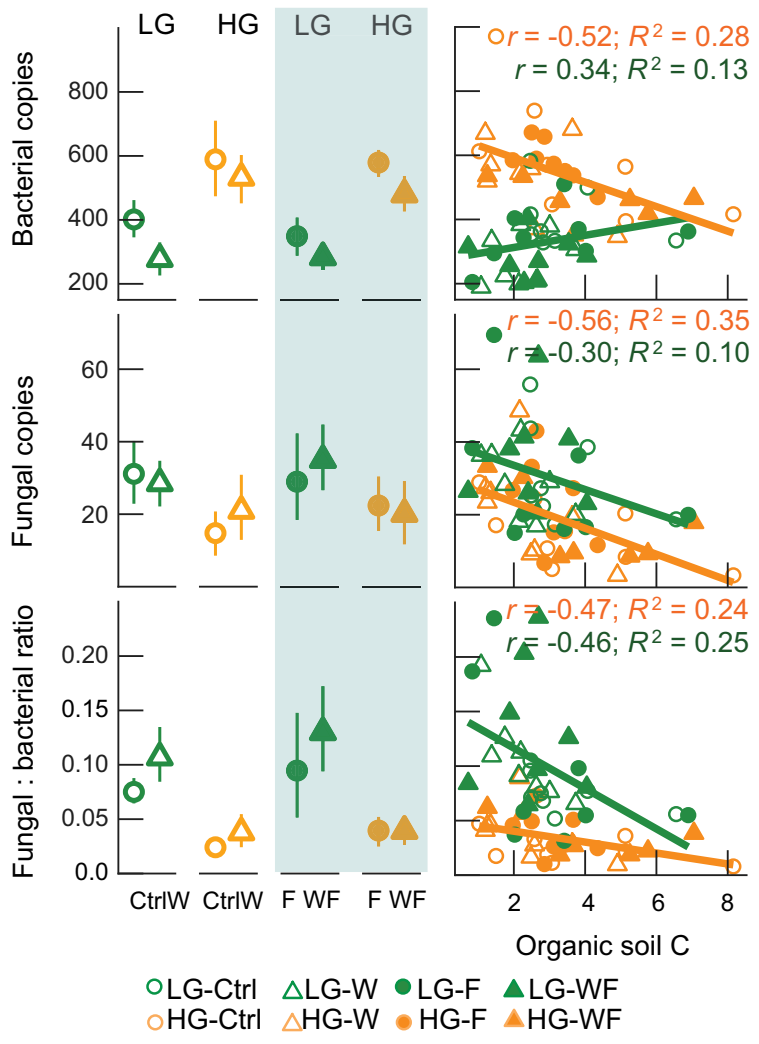

FIG. 5. Total number of bacterial 16S rRNA and fungal ITS2 gene copies in organic soil $\left(10^{6}\right.$ copies $\left.\mathrm{g} / \mathrm{SOM}\right)$ and the soil fungal: bacterial ratio (based on the above copies) and their correlations with the organic soil layer carbon stocks $\left(\mathrm{kg} \mathrm{C} / \mathrm{m}^{2}\right)$ under the long-term grazing intensities. Values on the left represent means and $95 \%$ confidence intervals based on a bootstrap in control (Ctrl), warmed (W), fertilized (F), and warmed and fertilized (WF) plots under light grazing (LG) and heavy grazing $(\mathrm{HG} ; n=8)$. On the right panel, linear correlations are presented for both grazing areas separately $(r$, Pearson correlation coefficient; $R^{2}$, coefficient of determination).

Fertilization increased soil moisture $(P=0.008$, Table 1) and had a positive effect on the total EEA $(P<0.001$, Appendix S1: Table S5). However, fertilization effect on the individual enzymes was divergent: the potential activities of $\beta$-glucosidase, $\beta$-N-acetylglucosaminidase, and acid phosphatase increased with fertilization, whereas the activities of leucine aminopeptidase and urease decreased (Appendix S1: Table S4, Fig. S5). By increasing the amount of inorganic $\mathrm{N}$ per area (Table 1; Appendix S1: Fig. S2), fertilization decreased soil C:N ratio. Interestingly, the positive effect of fertilization on soil $\mathrm{NH}_{4}^{+}-\mathrm{N}$ concentration was stronger in the warmed plots $(\mathrm{W} \times \mathrm{F}, P=0.006$, Table 1). Furthermore, fertilization had a positive effect on the ratio between fungal and bacterial copy numbers (Table 1, $P=0.038$; Fig. 5).

Microbial copy numbers explained part of the variation in soil organic carbon stocks (Fig. 5). Under heavy grazing, $28 \%$ of the variation in soil organic carbon stocks was explained by the number of bacterial copies, and $35 \%$ by the number of fungal copies. Under LG, the percentage of explained variation was smaller, $13 \%$ and $10 \%$ for bacterial and fungal copy numbers, respectively. Under both grazing intensities, the ratio between fungal and bacterial copy numbers correlated negatively with organic soil carbon stocks.

\section{DisCUSSION}

In this study, we investigated the effects of experimental warming and enhanced nitrogen availability on ecosystem carbon storage in two long-term grazing regimes and under a sudden cessation of grazing in subarctic tundra. While we found no effect of treatments on total ecosystem carbon storage, experimental warming induced a uniform decline in organic soil carbon across all grazing intensities. Notably, the effect of warming depended on soil nitrogen availability and grazing, demonstrating that multiple global changes simultaneously determine the realized changes in ecosystems (sensu Tylianakis et al. 2008). More specifically, enhanced nitrogen availability counteracted the warming-induced organic soil carbon loss under both longterm grazing regimes but not when grazing was abruptly stopped. By inspecting the pathways from the treatments to changes in organic soil carbon, we could further conclude that the drivers of soil carbon stock changes were different under all grazing intensities.

\section{Warming-induced soil carbon loss regardless of shrubification}

Here we showed that warming in general decreased carbon in the organic soil layer, while it increased carbon in the mineral soil layer. Although in another study in a tussock tundra, a warming-induced carbon translocation to deeper soil layers was shown to compensate for the organic soil carbon losses (Sistla et al. 2013), at our site, the magnitude of mineral soil carbon gain was far smaller than the carbon loss in the organic soil layer. Therefore, these results add to a growing body of evidence that climate warming may induce soil carbon losses in high latitudes (Koven et al. 2017, Phillips et al. 2018). In contrast to our hypothesis, the observed declines in soil organic carbon were similar at all grazing intensities although both the dominant vegetation and the microbial community composition differed drastically between the long-term grazing intensities (Väisänen et al. 2014, Männistö et al. 2016). Thus, the similar responses to warming under seemingly different settings imply that rapid decreases in soil carbon can occur also in the absence of shrubs and shrubification. Furthermore, different soil biota may have been driving the warming-induced soil carbon losses depending on grazing intensity.

Despite a similar outcome of warming on soil carbon stocks across all grazing regimes, we found that the 
organic soil carbon losses were likely induced by different drivers under contrasting long- and short-term grazing patterns (Fig. 2). At all grazing intensities, lower soil carbon stocks were linked to a higher sum of extracellular enzyme activities supporting the theory that microbial synthesis of extracellular enzymes plays a pivotal role in soil carbon degradation (Allison et al. 2007, Sinsabaugh et al. 2008). However, warming affected potential enzymatic activities in two ways: the sum of analysed EEAs decreased as a direct response to warming, which seems likely explained by the warming-induced decline in the activity of acid phosphatase, the most ubiquitous EEA at the site (as also in Phillips et al. 2018, Stark et al. 2018). Yet to the contrary, the warming-induced decrease in soil moisture had a positive effect on the potential EEAs.

The structural equation model indicates that, under light grazing, the warming treatment was linked to an increased proportion of shrubs in the vegetation, which, in turn, contributed to a lower soil carbon storage. This is in line with the previous observations showing that, a high abundance of deciduous shrubs is associated with low soil carbon storage, possibly due to high ectomycorrhizal activity under the shrubs (Hartley et al. 2012, Parker et al. 2015, 2018). In our study, deciduous shrub abundance under light grazing was $79 \%$ higher in warmed than control plots, while organic soil carbon stocks were 33\% lower, which is comparable to the observed natural differences in soil organic carbon under varying deciduous shrub cover (Parker et al. 2015). We acknowledge that the observed pattern in soil carbon stocks might be partly induced by initial differences between plots assigned for control and warming treatments (Appendix S1: Fig. S5). Yet, during the experiment, shrub abundance in the warmed plots under light grazing increased by $50.9 \%$, suggesting a positive response of deciduous shrubs to warming, a result commonly found in tundra warming experiments (Myers-Smith et al. 2011).

In contrast to the lightly grazed tundra, the structural equation model links the warming-induced changes in the heavily grazed tundra to decreased soil moisture. The drier soils led to lower soil carbon stocks both directly and by increasing potential EEAs and, possibly also, through inducing changes to the fungal and bacterial communities. Furthermore, in short-term exclosures warming had a direct negative effect on soil organic carbon. Although our structural model might not have encompassed all factors underlying the soil carbon loss, the different pathways under the different grazing intensities strongly suggest that different underlying mechanisms can contribute to a similar outcome of warming. It is notable, that the observed carbon loss in response to warming was rapid and vast when compared to other reports showing slower and more modest responses (Phillips et al. 2018) or no net response to warming (Sistla et al. 2013). These demonstrate the particular susceptibility of our site to warming, as even a short-term increase in summer temperatures, with or without shrubification, could induce large changes in soil carbon storage equal to those currently observed under differing shrub abundance.

\section{Grazer-dependent outcome to combined warming and fertilization}

Whereas the consequences of warming on soil organic carbon stocks were uniform across the grazing intensities, the consequences of warming in combination with fertilization revealed grazer-dependent responses in organic soil carbon. Fertilization negated the warminginduced carbon loss from organic soil under long-term light and heavy grazing but not within short-term exclosures. These findings show that the commonly occurring global changes may have interactive effects on soil carbon storage (as in Tylianakis et al. 2008, Callaghan et al. 2013). More precisely, ecosystem responses to abiotic changes, such as warmer temperatures and higher nitrogen availability, may be particularly complicated to predict when they occur simultaneously with changes in biota (Post et al. 2009, Blois et al. 2013) and land use (Hoegh-Guldberg et al. 2018).

The finding that fertilization negated the warminginduced carbon losses contrasts previous results of negative fertilization effects on soil carbon (Mack et al. 2004). In their study, Mack et al. reported that the fertilizationdriven soil carbon loss was accompanied with an increased abundance of deciduous shrubs, whereas in our study, fertilization led to higher abundance of graminoids and lower abundance of bryophytes and thereby increased litter quantity across all grazing intensities. We suggest that this fertilization-induced plant carbon input in the form of graminoid litter and bryophyte necromass may have negated the warming-induced soil carbon loss under both long-term grazing intensities. The higher substrate availability may have also increased carbon and nitrogen decomposition (Hernández and Hobbie 2010) as indicated by the higher microbial extracellular enzymatic activities.

It is notable that the effects of the short-term grazer exclusion on litter cover and EEAs were very similar to the effects of the combined warming and fertilization treatment. We suggest that the combined effects may have prompted the destabilization of accumulated soil carbon in the combined warming and fertilization treatment within the exclosures, thus explaining the threefactorial interaction. In the absence of grazing, the biomass accumulation in the exclosures possibly enhanced labile substrate availability for decomposers (Francini et al. 2014), whose activity may further have been boosted by the positive legacy of long-term heavy grazing on soil nutrient availability (Egelkraut et al. 2018).

\section{Soil carbon storage the same regardless of short- and long-term differences in grazing}

In this study, we found no difference between the long-term grazing regimes in ecosystem carbon storage. 
This result contrasted our hypothesis of greater carbon storage under light than heavy grazing that was based on the previously reported higher ecosystem carbon sink under light grazing (Väisänen et al. 2014), but is coherent with historical grazing sites where a grazing-induced vegetation differences did not influence soil carbon storage (Stark et al. 2019), previous reports from the same study site (Ylänne et al. 2018) and other subarctic areas (Köster et al. 2013, 2015). The inconsistent results between carbon stocks and growing season fluxes are in line with other observations reporting inconsistencies between changes in soil carbon stocks and growing season midday carbon fluxes (Chapin et al. 2009, Sørensen et al. 2018). In general, carbon stock changes in the tundra could be more dependent on non-growing season processes (Wipf and Rixen 2010, Cooper 2014), especially under shrub canopies (Grogan 2012). Yet, at our site, no differences in soil respiration were found during the first winter of the study (2010-2011; Väisänen et al. 2014).

Although short-term exclusion of grazers induced no impact on ecosystem carbon storage, it is noteworthy that in terms of vegetation and soil processes, the sudden cessation of grazing did not increase the ecosystem resemblance to the state with a decadal history of light grazing. The exclusion of grazing amplified the changes induced by decadal heavy grazing intensity (Olofsson et al. 2004, Stark and Väisänen 2014) by increasing vascular vegetation and graminoids, decreasing bryophytes and increasing microbial activity for carbon decomposition. Thus, instead of bringing the system towards a state prior to grazing, our results suggest that grazer exclusion may induce a further shift of an ecosystem. Also, other studies have shown that if grazing suddenly stops at a site with long history of heavy grazing, ecosystem responses may diverge from the ones caused by long-term differences in grazing intensities (Haynes et al. 2014). These controversial outcomes may happen because the grazing-induced changes in ecosystem processes become independent of the actual grazing event (Stark and Väisänen 2014, Egelkraut et al. 2018).

\section{Conclusions}

The results of this paper deepen our understanding of the interacting effects of warming and nitrogen availability on soil carbon storage across cold regions (in line with previous studies, such as Weintraub and Schimel [2005] and Zamin et al. [2014]). Moreover, they also reveal that differences in the grazing intensity of reindeer could interfere with the abiotic environmental changes. Not only did the consequences of warming and enhanced nitrogen availability on tundra soil carbon depend on a sudden change in grazing intensity, but grazing also determined the mechanisms underlying warming-induced changes in soil carbon. This potentially decisive role of reindeer in sealing the fate of tundra soil carbon and the circumpolar distribution of reindeer and caribou warns that the existing projections of the carbon-climate feedback might hold true only under certain grazing regimes. Furthermore, now that reindeer populations and their migration routes are changing drastically across the tundra (Uboni et al. 2016) and are likely to change even further due to ongoing environmental and societal changes (Forbes et al. 2016), the projections of changes in soil carbon storage do not account for altered grazing patterns and their interactions with other global changes.

\section{ACKNOWLEDGMENTS}

We would like to thank Aarno Niva, Sirkka Aakkonen, Aura Pyysalo, and Eero Myrsky for their contribution to the fieldwork, Carolina de la Rosa, Tarja Törmänen, and Sirkka Aakkonen for the help with processing and analyzing the samples, and Ahma Laboratory for conducting the $\mathrm{C}$ and $\mathrm{N}$ analyses. Professors Paul Grogan, Jukka Pumpanen, and Richard Bardgett are thanked for their highly useful comments on previous versions of the manuscript. All authors contributed significantly to the writing of the manuscript. The field setting was designed by S. Stark, J. Olofsson, and M. Väisänen, field manipulations were performed by $M$. Väisänen, H. Ylänne, and S. Stark. E. Kaarlejärvi and H. Ylänne conducted vegetation abundance measurements. $\mathrm{M}$. Väisänen analysed soil microbial activities and M. Männistö and S. H. K. Ahonen analyzed soil microbial community composition. H. Ylänne analyzed ecosystem carbon stocks, performed all the statistical analyses, and led the writing of the manuscript. Financial support to the work has been provided by the Academy of Finland (decision numbers 218121 and 130507 to S. Stark and decision number 310776 to Max Häggblom), Maj and Tor Nessling Foundation (to S. Stark), Kone Foundation (to H. Ylänne), the Swedish Research Council (2015-00498 to E. Kaarlejärvi), Lapland Regional Fund of Finnish Cultural Foundation (to M. Väisänen), and Northern Ostrobothnian Regional Fund of Finnish Cultural Foundation (to H. Ylänne).

\section{Literature Cited}

Allison, S. D., T. B. Gartner, K. Holland, M. N. Weintraub, and R. L. Sinsabaugh. 2007. Soil enzymes : linking proteomics and ecological processes. Pages 704-771 in C. Hurst, R. Crawford, J. Garland, D. Lipson, A. Mills, and L. Stetzenbach, editors. Manual of environmental microbiology. Third edition. ASM Press, Washington, D.C., USA.

Allison, S. D., C. I. Czimzik, and K. K. Treseder. 2008. Microbial activity and soil respiration under nitrogen addition in Alaskan boreal forest. Global Change Biology 14:1156-1168.

Barthelemy, H., S. Stark, M. M. Kytöviita, and J. Olofsson. 2017. Grazing decreases N partitioning among coexisting plant species. Functional Ecology 31:2051-2060.

Belshe, E. F., E. A. G. Schuur, and B. M. Bolker. 2016. Tundra ecosystems observed to be $\mathrm{CO}_{2}$ sources due to differential amplification of the carbon cycle. Ecology Letters 16:13071315.

Blois, J. L., P. L. Zarnetske, M. C. Fitzpatrick, and S. Finnegan. 2013. Climate change and the past, present, and future of biotic interactions. Science 341:499-504.

Boerner, R. E. J., K. L. M. Decker, and E. K. Sutherland. 2000. Prescribed burning effects on soil enzyme activity in a southern Ohio hardwood forest: a landscape-scale analysis. Soil Biology \& Biochemistry 32:899-908. 
Bokhorst, S., A. D. Huiskes, P. Convey, B. J. Sinclair, M. Lebouvier, B. Van de Vijver, and D. H. Wall. 2011. Microclimate impacts of passive warming methods in Antarctica: implications for climate change studies. Polar Biology 34:1421-1435.

Bråthen, K. A., V. T. Ravolainen, A. Stien, T. Tveraa, and R. A. Ims. 2017. Rangifer management controls a climate-sensitive tundra state transition. Ecological Applications 27:24162427

Cahoon, S. M. P., P. F. Sullivan, E. Post, and J. M. Welker. 2012. Large herbivores limit $\mathrm{CO}_{2}$ uptake and suppress carbon cycle responses to warming in West Greenland. Global Change Biology 18:469-479.

Callaghan, T. V., et al. 2013. Ecosystem change and stability over multiple decades in the Swedish subarctic: complex processes and multiple drivers. Philosophical Transactions of the Royal Society B 368:20120488.

Chapin, F. S., J. McFarland, A. David McGuire, E. S. Euskirchen, R. W. Ruess, and K. Kielland. 2009. The changing global carbon cycle: linking plant-soil carbon dynamics to global consequences. Journal of Ecology 97:840-850.

Choudhary, S., A. Blaud, A. M. Osborn, M. C. Press, and G. K. Phoenix. 2016. Nitrogen accumulation and partitioning in a High Arctic tundra ecosystem from extreme atmospheric N deposition events. Science of the Total Environment 554 555:303-310.

Cooper, E. J. 2014. Warmer shorter winters disrupt arctic terrestrial ecosystems. Annual Review of Ecology, Evolution, and Systematics 45:271-295.

Egelkraut, D., K. Å. Aronsson, A. Allard, M. Åkerholm, S. Stark, and J. Olofsson. 2018. Multiple feedbacks contribute to a centennial legacy of reindeer on tundra vegetation. Ecosystems 21:1545-1563.

Forbes, B. C., et al. 2016. Sea ice, rain-on-snow and tundra reindeer nomadism in Arctic Russia. Biology Letters 12:20160466.

Francini, G., M. Liiri, M. Männistö, S. Stark, and M. M. Kytöviita. 2014. Response to reindeer grazing removal depends on soil characteristics in low Arctic meadows Applied Soil Ecology 76:14-25.

Griffiths, R., and A. Whiteley. 2000. Rapid method for coextraction of DNA and RNA from natural environments for analysis of ribosomal DNA- and rRNA-based microbial community composition. Applied and Environmental Microbiology 66:5488-5491.

Grogan, P. 2012. Cold season respiration across a low arctic landscape: the influence of vegetation type, snow depth, and interannual climatic variation. Arctic, Antarctic, and Alpine Research 44:446-456.

Hartley, I. P., D. W. Hopkins, M. Sommerkorn, and P. A. Wookey. 2010. The response of organic matter mineralisation to nutrient and substrate additions in sub-arctic soils. Soil Biology and Biochemistry 42:92-100.

Hartley, I. P., M. Garnett, M. Sommerkorn, D. W. Hopkins, B. J. Fletcher, V. L. Sloan, G. K. Phoenix, and P. A. Wookey. 2012. A potential loss of carbon associated with greater plant growth in the European Arctic. Nature Climate Change 2:875-879.

Haynes, A. G., M. Schütz, N. Buchmann, D. S. Page-Dumroese, M. D. Busse, and A. C. Risch. 2014. Linkages between grazing history and herbivore exclusion on decomposition rates in mineral soils of subalpine grasslands. Plant and Soil 374:579-591.

Hernández, D. L., and S. E. Hobbie. 2010. The effects of substrate composition, quantity, and diversity on microbial activity. Plant and Soil 335:397-411.

Hoegh-Guldberg, O., et al. 2018. Chapter 3: Impacts of $1.5^{\circ} \mathrm{C}$ global warming on natural and human systems. Pages 175 311 in V. Masson-Delmotte, et al., editors. Global warming of $1.5^{\circ} \mathrm{C}$ : an IPCC special report on the impacts of global warming of $1.5^{\circ} \mathrm{C}$ above pre-industrial levels and related global greenhouse gas emission pathways, in the context of strengthening the global response to the threat of climate change. International Panel on Climate Change, Cambridge University Press, Cambridge.

Ihrmark, K., et al. 2012. New primers to amplify the fungal ITS2 region-evaluation by 454-sequencing of artificial and natural communities. FEMS Microbiology Ecology 82:666-677.

Jassey, V. E. J., et al. 2018. Tipping point in plant-fungal interactions under severe drought causes abrupt rise in peatland ecosystem respiration. Global Change Biology 24:972-986.

Jiang, Y., A. V. Rocha, E. B. Rastetter, G. R. Shaver, U. Mishra, Q. Zhuang, and B. L. Kwiatkowski. 2016. C-N-P interactions control climate driven changes in regional patterns of $\mathrm{C}$ storage on the North Slope of Alaska. Landscape Ecology $31: 195-213$

Köster, E., K. Köster, M. Aurela, T. Laurila, F. Berninger, A. Lohila, and J. Pumpanen. 2013. Impact of reindeer herding on vegetation biomass and soil carbon content: a case study from Sodankylä, Finland. Boreal Environment Research $18: 35-42$.

Köster, K., F. Berninger, E. Köster, and J. Pumpanen. 2015. Influences of reindeer grazing on above-and below-ground biomass and soil carbon dynamics influences of reindeer grazing on above-and below- ground biomass and soil carbon dynamics. Arctic, Antarctic, and Alpine Research 47:495-503.

Koven, C. D., G. Hugelius, D. M. Lawrence, and W. R. Wieder. 2017. Higher climatological temperature sensitivity of soil carbon in cold than warm climates. Nature Climate Change 7:817-822.

Kühnel, R., M. P. Björkman, C. P. Vega, A. Hodson, E. Isaksson, and J. Ström. 2013. Reactive nitrogen and sulphate wet deposition at Zeppelin Station, Ny-Ålesund, Svalbard. Polar Research 32:1-14.

Lefcheck, J. 2016. piecewiseSEM: piecewise structural equation modelling in $\mathrm{r}$ for ecology, evolution, and systematics. Methods in Ecology and Evolution 7:573-579.

Lenth, R. V. 2016. Least-squares means: the R package lsmeans. Journal of Statistical Software 69:1-33.

Mack, M. C., E. A. Schuur, M. S. Bret-Harte, G. R. Shaver, and F. S. I. Chapin. 2004. Ecosystem carbon storage in arctic tundra reduced by long-term nutrient fertilization. Nature 431:440-443.

Maestre, F. T., et al. 2012. Plant Species richness and ecosystems multifunctionality in global drylands. Science 335:2014 2017.

Männistö, M., L. Ganzert, M. Tiirola, M. M. Häggblom, and S. Stark. 2016. Do shifts in life strategies explain microbial community responses to increasing nitrogen in tundra soil? Soil Biology and Biochemistry 96:216-228.

Mazerolle, M. J. 2017. AICcmodavg: model selection and multimodel inference based on (Q)AIC(c). http://CRAN.R-projec t.org/package $=$ AICcmodavg

Metcalfe, D. B., and J. Olofsson. 2015. Distinct impacts of different mammalian herbivore assemblages on arctic tundra $\mathrm{CO}_{2}$ exchange during the peak of the growing season. Oikos 124:1632-1638.

Muyzer, G., E. C. De Waal, and A. G. Uitterlinden. 1993. Profiling of complex microbial populations by denaturing gradient gel electrophoresis analysis of polymerase chain reaction-amplified genes coding for $16 \mathrm{~S}$ rRNA. Applied and Environmental Microbiology 59:695-700.

Myers-Smith, I. H., et al. 2011. Shrub expansion in tundra ecosystems: dynamics, impacts and research priorities. Environmental Research Letters 6:045509.

Olofsson, J., H. Kitti, P. Rautiainen, S. Stark, and L. Oksanen. 2001. Effects of summer grazing by reindeer on composition of 
vegetation, productivity and nitrogen cycling. Ecography 24:13-24.

Olofsson, J., S. Stark, and L. Oksanen. 2004. Reindeer influence on ecosystem processes in the tundra. Oikos 2:386-396.

Olofsson, J., L. Oksanen, T. Callaghan, P. E. Hulme, T. Oksanen, and O. Suominen. 2009. Herbivores inhibit climatedriven shrub expansion on the tundra. Global Change Biology 15:2681-2693.

Parker, T. C., J. A. Subke, and P. A. Wookey. 2015. Rapid carbon turnover beneath shrub and tree vegetation is associated with low soil carbon stocks at a subarctic treeline. Global Change Biology 21:2070-2081.

Parker, T. C., J. Sanderman, R. D. Holden, G. Blume-Werry, S. Sjögersten, D. Large, M. Castro-Díaz, L. E. Street, J. A. Subke, and P. A. Wookey. 2018. Exploring drivers of litter decomposition in a greening Arctic: results from a transplant experiment across a treeline. Ecology 99:2284-2294.

Phillips, C. A., B. Elberling, and A. Michelsen. 2018. Soil carbon and nitrogen stocks and turnover following 16 years of warming and litter addition. Ecosystems 22:110-124.

Pinheiro, J., D. Bates, S. DebRoy, D. Sarkar, and R Core Team. 2014. nlme: linear and nonlinear mixed effects models. https://CRAN.R-project.org/package $=$ nlme

Post, E., et al. 2009. Ecological dynamics across the Arctic associated with recent climate change. Science 325:1355-1358.

R Core Team. 2012. R: a language and environment for statistical computing. R Foundation for Statistical Computing, Vienna, Austria. www.R-project.org

Ravolainen, V. T., K. A. Bråthen, R. A. Ims, N. G. Yoccoz, J. A. Henden, and S. T. Killengreen. 2011. Rapid, landscape scale responses in riparian tundra vegetation to exclusion of small and large mammalian herbivores. Basic and Applied Ecology 12:643-653.

Shipley, B. 2009. Confirmatory path analysis in a generalized multilevel context. Ecology 90:363-368.

Sinsabaugh, R. L., H. Reynolds, and T. M. Long. 2000. Rapid assay for amidohydrolase (urease) activity in environmental samples. Soil Biology and Biochemistry 32:2095-2097.

Sinsabaugh, R. L., et al. 2008. Stoichiometry of soil enzyme activity at global scale. Ecology Letters 11:1252-1264.

Sistla, S. A., J. C. Moore, R. T. Simpson, L. Gough, G. R. Shaver, and J. P. Schimel. 2013. Long-term warming restructures Arctic tundra without changing net soil carbon storage. Nature 497:615-618.

Sjögersten, S., R. van der Wal, and S. J. Woodin. 2012. Impacts of grazing and climate warming on $\mathrm{C}$ pools and decomposition rates in arctic environments. Ecosystems 15:349-362.

Sørensen, M. V., R. Strimbeck, K. O. Nystuen, R. E. Kapas, B. J. Enquist, and B. J. Graae. 2018. Draining the pool? Carbon storage and fluxes in three alpine plant communities. Ecosystems 21:316-330.

Stark, S., and M. Väisänen. 2014. Insensitivity of soil microbial activity to temporal variation in soil $\mathrm{n}$ in subarctic tundra: evidence from responses to large migratory grazers. Ecosystems 17:906-917.

Stark, S., H. Ylänne, and A. Tolvanen. 2018. Long-term warming alters soil and enzymatic N: P stoichiometry in subarctic tundra. Soil Biology and Biochemistry 124:184-188.

Stark, S., D. Egelkraut, K. Å. Aronsson, and J. Olofsson. 2019. Contrasting vegetation states do not diverge in soil organic matter storage: evidence from historical sites in tundra. Ecology 100:1-14.

Street, L. E., N. Mielke, and S. J. Woodin. 2018. Phosphorus availability determines the response of tundra ecosystem carbon stocks to nitrogen enrichment. Ecosystems 21:1155-1167.

Tarnocai, C., J. G. Canadell, E. A. G. Schuur, P. Kuhry, G. Mazhitova, and S. Zimov. 2009. Soil organic carbon pools in the northern circumpolar permafrost region. Global Biogeochemical Cycles 23. https://doi.org/10.1029/2008gb003327

te Beest, M., J. Sitters, C. B. Ménard, and J. Olofsson. 2016. Reindeer grazing increases summer albedo by reducing shrub abundance in Arctic tundra. Environmental Research Letters 11:125013.

Tylianakis, J. M., R. K. Didham, J. Bascompte, and D. A. Wardle. 2008. Global change and species interactions in terrestrial ecosystems. Ecology Letters 11:1351-1363.

Uboni, A., T. Horstkotte, E. Kaarlejärvi, A. Seveque, F. Stammler, J. Olofsson, B. C. Forbes, and J. Moen. 2016 Long-term trends and role of climate in the population dynamics of Eurasian reindeer. PLoS ONE 11:1-20.

Väisänen, M., H. Ylänne, E. Kaarlejärvi, S. Sjögersten, J. Olofsson, N. Crout, and S. Stark. 2014. Consequences of warming on tundra carbon balance determined by reindeer grazing history. Nature Climate Change 4:384-388.

Weintraub, M. N., and J. P. Schimel. 2005. Nitrogen cycling and the spread of shrubs control changes in the carbon balance of arctic tundra ecosystems. BioScience 55:408.

White, T. J., S. Bruns, S. Lee, and J. Taylor. 1990. Amplification and direct sequencing of fungal ribosomal RNA genes for phylogenetics. Academic Press, New York, New York, USA.

Wipf, S., and C. Rixen. 2010. A review of snow manipulation experiments in Arctic and alpine tundra ecosystems. Polar Research 29:95-109.

Ylänne, H., J. Olofsson, L. Oksanen, and S. Stark. 2018. Consequences of grazer-induced vegetation transitions on ecosystem carbon storage in the tundra. Functional Ecology 32:1091-1102.

Zamin, T. J., M. S. Bret-Harte, and P. Grogan. 2014. Evergreen shrubs dominate responses to experimental summer warming and fertilization in Canadian mesic low arctic tundra. Journal of Ecology 102:749-766.

Zimov, N. S., S. A. Zimov, A. E. Zimová, G. M. Zimová, V. I. Chuprynin, and F. S. Chapin. 2009. Carbon storage in permafrost and soils of the mammoth tundra-steppe biome: role in the global carbon budget. Geophysical Research Letters $36: 2-7$.

\title{
SUPPORTING INFORMATION
}

Additional supporting information may be found online at: http://onlinelibrary.wiley.com/doi/10.1002/ecm.1396/full

\author{
Data Availability
}

Data are available on Dryad: https://doi.org/10.5061/dryad.69p8cz8xb. 